\section{UFGE 4141, UFGE 7014, UFGE 7015, UFGE 7023, UFGE 7032, and UFGE 7034: Six New Gerbera Cultivars for Marketing Flowering Plants in Large Containers}

\author{
Zhanao Deng ${ }^{1}$ and Brent K. Harbaugh \\ University of Florida, IFAS, Environmental Horticulture Department, Gulf \\ Coast Research and Education Center, 14625 County Road 672, Wimauma, \\ FL 33598
}

Additional index words. Gerbera hybrida, Gerbera jamesonii, Gerbera viridifolia, plant breeding

Gerbera (Asteraceae Dumont) is one of the most important floricultural crops in the United States and worldwide (Behnke, 1984; Rogers and Tjia, 1990). It has been commercially produced in Europe since the turn of the 20th century and in North America since the early 1920s (Rogers and Tjia, 1990). Continuous introduction of new cultivars with improved or novel horticultural characteristics has been one of the major driving forces for the popularity of this flower (Behnke, 1984; Rogers and Tjia, 1990).

Gerbera breeding was pioneered in England in the 1890s (Hansen, 1999) and has been conducted in The Netherlands, the United States, Demark, Germany, Israel, and other countries. For the past several decades, commercial breeding programs have focused efforts primarily on developing cultivars for cut flower production or for flowering pot plant production (Behnke, 1984; Rogers and Tjia, 1990). Cut flower cultivars are required to produce flowers with long peduncles (greater than $50 \mathrm{~cm}$ ), and the majority of the pot gerbera cultivars have been developed for production in 15-cm-diameter or smaller containers; thus, they produce compact foliage and flowers with short peduncles (less than $25 \mathrm{~cm}$ ) (Dole and Wilkins, 1999). Recently, interest in producing gerberas in large (trade gallon or larger) containers for indoor or outdoor use is increasing [O. Nissen (Sunshine Carnations State, Inc.) and J. Mazat (Ball Horticultural

Received for publication 10 Mar. 2010. Accepted for publication 12 Apr. 2010.

We thank Sunshine State Carnations, Inc. and the Fred C. Gloeckner Foundation, Inc. for providing financial support for some of the breeding activities toward the development of these gerbera cultivars, and Gail Bowman, Richard Kelly, Nancy West, Joyce Jones, and Li Gong for their excellent technical support. Agri-Starts, Inc. donated the tissue culture liners for all the experiments reported herein, Ball Horticultural Company, Costa Farms, and Pure Beauty Farms conducted growers' trials of these new gerbera cultivars.

${ }^{1}$ To whom reprint requests should be addressed; e-mail zdeng@ufl.edu.
Company), personal communication]. Grower trials have indicated a severe lack of suitable cultivars for such use (Channel, 2005). To produce gerberas for such a market, growers have had either to use cut flower cultivars and growth retardants to shorten the flower peduncles or to use pot-type cultivars bred for small containers. Gerbera plants so produced are generally of low quality and do not perform well in large containers: plants being too small, compact, and not able to cover the containers or flowers being too tall and leggy. Growers are in need of new gerbera cultivars suitable for such a niche market.

UFGE 4141, UFGE 7014, UFGE 7015, UFGE 7023, UFGE 7032, and UFGE 7034 have been selected and tested specifically to meet the needs of the large-container flowering gerbera market. They have produced highquality plants in trade gallon containers and produced many bright-colored flowers. Replicated greenhouse trials have also shown that these gerberas flowered earlier and produced more flowers than control cultivars. Additionally, these gerberas, especially UFGE 7015, are more resistant to powdery mildew, the most common and damaging fungal disease in gerbera production and use (Chase, 2001; Moyer and Peres, 2008). These improvements should be beneficial to growers and consumers who produce or use gerberas in large containers.

\section{Origin}

UFGE 4141 is a progeny of a cross between selections UFGE 5-23 and UFGE 4-8 that was made in Spring 2003 (Fig. 1) and was initially selected in Summer 2004.

UFGE 7014 and UFGE 7015 resulted from a cross between 'Sunburst Snow White' and selection UFGE 4033 (Fig. 1) and were initially selected as 7-157-12 and 7-157-13 in late 2007. UFGE 4033 was a progeny of the cross between UFGE 31-19 and UFGE 35-4.

UFGE 7023 was selected in late 2007 out of a population of progeny of selection UFGE 5003 and 'Sunburst Yellow' (Fig. 1). UFGE
5003 was progeny of the cross 'Swift Yellow' and UFGE 31-19 and was initially selected as 4-3-15 in 2005.

UFGE 7032 and UFGE 7034 both resulted from a cross between selection UFGE 5006 and 'Sunburst Yellow' (Fig. 1) and were initially selected as 7-68-4 and 7-68-8, respectively, in late 2007. UFGE 5006 resulted from crossing UFGE 39-26 and UFGE 5-23 and was selected as 4-41-3 in 2005.

UFGE 4-8, UFGE 5-23, UFGE 31-19, UFGE 35-4, and UFGE 39-26 were selected out of $\approx 2000$ progeny of seeds donated by Sunshine State Carnations, Inc. (Hobe Sound, FL). 'Sunburst Snow White', 'Sunburst Yellow', and 'Swift Yellow' were unpatented commercial pot gerbera cultivars.

\section{Description}

Descriptions of color [e.g., Royal Horticultural Society (RHS) 200B] for plant parts are based on comparison with the Royal Horticultural Society Color Chart (Royal Horticultural Society, 1986). Plants used for color description were grown in 20-cm-diameter containers $(\approx 3800 \mathrm{~mL})$ in a $30 \%$ shaded greenhouse and were 3.5 months old produced from tissue culture liners. Plant height and width descriptions were the average of eight plants grown in Fall 2009 and flower size the average of more than 25 flowers.

Mature plants of UFGE 4141 (Fig. 2-1a) had average heights of $52 \mathrm{~cm}$ and average widths of $65 \mathrm{~cm}$. Leaves were simple and pinnately lobed with deep lobes in the basal third, shallow lobes in the central third, and no obvious lobes near the top third. The upper and the lower leaf surface were medium green, RHS 146A and RHS 146B, respectively. Flowers (Fig. 2-1b) were semidouble and had an average diameter of $11.6 \mathrm{~cm}$. The upper and the lower sides of the outer ray florets were orange-red (RHS 33B) and yellow-orange (RHS 32C), respectively. Disc florets were orange-red (RHS 33A). Peduncles had average heights of $51.8 \mathrm{~cm}$.

Mature plants of UFGE 7014 (Fig. 2-2a) were $42 \mathrm{~cm}$ tall and $57 \mathrm{~cm}$ wide on average. Leaves were simple with medium lobes in the basal third, shallow lobes in the central third, and no obvious lobes near the top third. The upper leaf surface was medium green (RHS 146A). Flowers (Fig. 2-2b) were semidouble and had average sizes of $10.7 \mathrm{~cm}$ in diameter. The upper and the lower sides of the outer ray florets were white, RHS $155 \mathrm{D}$ and RHS 155B, respectively. Disc florets were white (RHS 155B). The average peduncle height of mature flowers was $41.9 \mathrm{~cm}$.

Mature plants of UFGE 7015 (Fig. 2-3a) had average heights of $39 \mathrm{~cm}$ and average widths of $45 \mathrm{~cm}$. Leaves were simple with medium lobes in the basal third and no obvious lobes in the central and top thirds. The upper and the lower sides of leaves were dark green (RHS 137B) and medium green (RHS 146B), respectively. Flowers (Fig. 2-3b) were semidouble and $10.2 \mathrm{~cm}$ in diameter on average. The upper side of the outer ray florets was light pink when flowers first open and changed to 

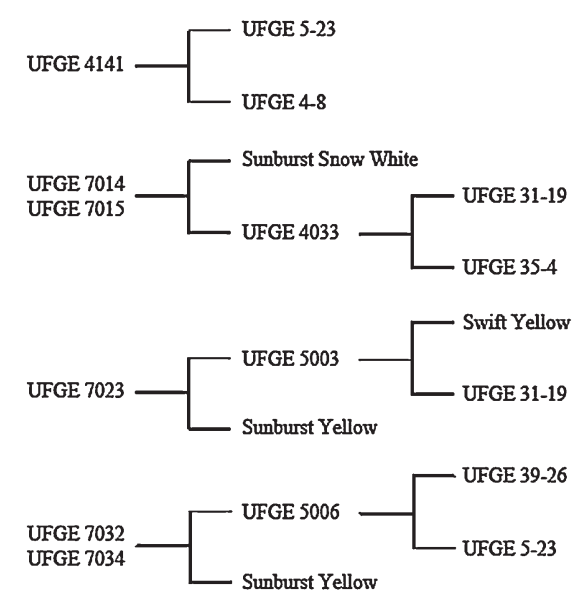

Fig. 1. Pedigree of UFGE 4141, UFGE 7014, UFGE 7015, UFGE 7023, UFGE 7032 and UFGE 7034. UFGE 4-8, UFGE 5-23, UFGE 31-19, UFGE 354 , and UFGE 39-26 were progeny selected out of $\approx 2000$ plants from seeds donated by Sunshine State Carnation, Inc. (Hobe Sound, FL). 'Sunburst Snow White', 'Sunburst Yellow', and 'Swift Yellow' were unpatented commercial cultivars. white (RHS 155D) as flowers mature. The lower surface of the outer ray florets was white (RHS 155B). Disc florets were white (RHS 155B). The average peduncle height was $39.0 \mathrm{~cm}$.

Mature plants of UFGE 7023 (Fig. 2-4a) had average heights of $42 \mathrm{~cm}$ and widths of 60 $\mathrm{cm}$. Leaves were simple, having deep lobes in the basal third and shallow or no obvious lobes in central and top thirds. The upper and the lower sides of leaves were yellow-green, RHS 144A and RHS 146C, respectively. Flowers (Fig. 2-4b) were semidouble and had a yellow color on the upper side (RHS 12A) and the lower side (RHS 12B) of the outer ray florets. Flowers averaged $12.1 \mathrm{~cm}$ in diameter. Disc florets were yellow (RHS 12C). Peduncles had average heights of $40.5 \mathrm{~cm}$.

Mature plants of UFGE 7032 (Fig. 2-5a) had average heights of $39 \mathrm{~cm}$ and widths of 55 $\mathrm{cm}$. Leaves were simple and pinnately lobed with deep lobes in the basal third, medium lobes in the central third, and shallow lobes near the top third. The upper leaf surface was dark green (RHS 147A). Flowers (Fig. 2-5b)
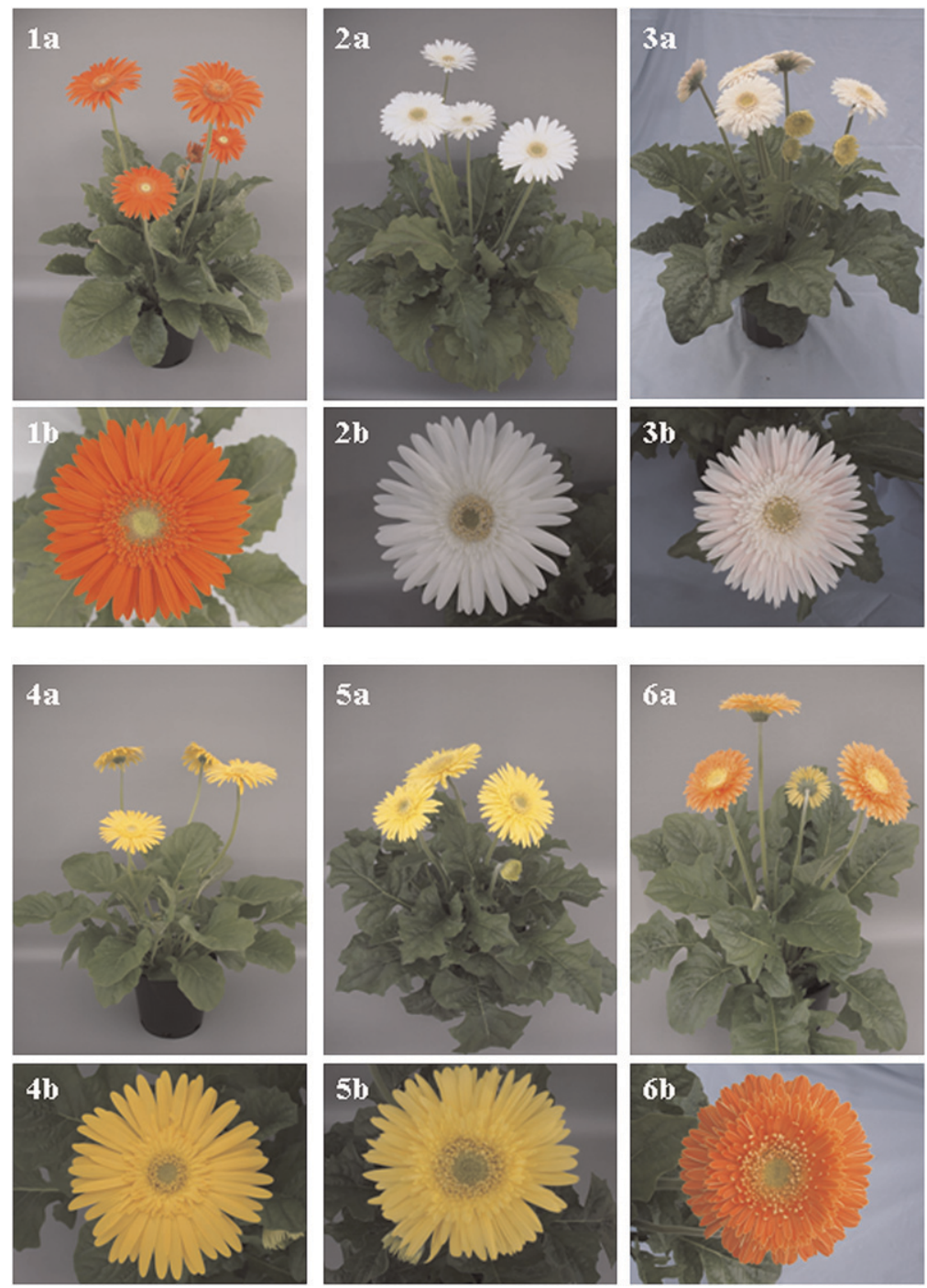

Fig. 2. Plant and flower of UFGE 4141 (1a-b), UFGE 7014 (2a-b), UFGE 7015 (3a-b), UFGE 7023 (4ab), UFGE 7031(5a-b), and UFGE 7034 (6a-b). All plants were grown from tissue culture liners in trade gallon plastic containers in the greenhouse for $\approx 2.5$ months. were semidouble and had an average size of $11 \mathrm{~cm}$ in diameter. Both the upper and lower sides of the outer ray florets were yellow (RHS $12 \mathrm{~A}$ and RHS 10B, respectively). Disc florets were yellow (RHS 10A). Peduncles of mature flowers had average heights of $37.9 \mathrm{~cm}$.

Mature plants of UFGE 7034 (Fig. 2-6a) had average heights of $40 \mathrm{~cm}$ and widths of 60 $\mathrm{cm}$. Leaves were simple and pinnately lobed with deep lobes in the basal third, shallow lobes in the central third, and no obvious lobes near the top third. The upper leaf surface was medium green (RHS 146A). Flowers (Fig. 2$6 \mathrm{~b})$ were full-double and had average sizes of $10.6 \mathrm{~cm}$ in diameter. The upper side of the outer ray florets was orange-red (RHS 30C), and the lower surface was yellow-orange (RHS 23C). Disc florets were yellow (RHS 13C). Peduncles of mature flowers had average heights of $38.9 \mathrm{~cm}$.

\section{Horticultural Characteristics}

Two experiments (Expt. 1 and Expt. 2) were conducted in the greenhouse with standard greenhouse management practices to evaluate these gerberas' horticultural characteristics: days to flower, flower size and quality, peduncle height, flowers produced over a 9week period (count), and plant quality. In Expt. 1, tissue culture liners (Agri-Starts, Apopka, FL) were transplanted on 9 Dec. 2008 into trade gallon containers filled with commercial potting mix Fafard 3B (Conrad Fafard, Inc., Agawam, MA) amended with the controlledrelease fertilizer Osmocote $(15 \mathrm{~N}-3.9 \mathrm{P}-10 \mathrm{~K}$; Scotts Co., Marysville, $\mathrm{OH}$ ) at a rate of 5.28 $\mathrm{kg} \cdot \mathrm{m}^{-3}$ and the trace element fertilizer MicroMax (Scotts Co.) at a rate of $1.05 \mathrm{~kg} \cdot \mathrm{m}^{-3}$. Potted plants were grown on metal benches in a glass house and spaced $46 \mathrm{~cm} \times 46 \mathrm{~cm}$ apart. Temperatures inside the greenhouse ranged from 18 to $33{ }^{\circ} \mathrm{C}$. Two hours of additional photoperiodic lighting (incandescent lamps, $\approx 15$ foot-candle, from $2200 \mathrm{HR}$ to $0000 \mathrm{HR}$ ) were provided between 9 Dec. 2008 and 17 Mar. 2009. Fungicides and insecticides were applied as needed to control powdery mildew (Moyer and Peres, 2008) and western flower thrips (Price et al., 2003). Flower quality was rated on a 1 to 5 scale: $1=$ very poor; $3=$ fair, some blemishes but acceptable; and $5=$ excellent, bright, uniform, and no blemishes. The number of flowers produced per plant was recorded weekly from 20 Jan. 2009 through 17 Mar. 2009. Plant quality was rated three times, on 20 Jan., 3 Feb., and 17 Feb. 2009, using a 1 to 5 scale: 1 = few leaves or long petioles, container surface visible, very poor and unacceptable as flowering pot plants; 3 = fair and marketable; and $5=$ excellent, full, symmetrical, attractive plants.

In Expt. 2, tissue culture liners (AgriStarts, Apopka, FL) were transplanted on 13 Aug. 2009 into trade gallon plastic containers filled with Fafard 3B potting mix (Conrad) as amended for Expt. 1. Plants were grown on metal benches in a greenhouse with spacing of $46 \mathrm{~cm} \times 46 \mathrm{~cm}$. The greenhouse was covered with aluminum shading cloth (Aluminet ${ }^{\circledR}$; Signature Supplies, Inc., Lakeland, FL) with 
$\approx 30 \%$ light exclusion. Greenhouse temperatures ranged from 21 to $35{ }^{\circ} \mathrm{C}$. Additional photoperiodic lighting $(2 \mathrm{~h})$ was provided beginning 15 Sept. 2009. Fungicides and insecticides were applied as needed to control powdery mildew and western flower thrips (Moyer and Peres, 2008; Price et al., 2003). Flower quality and plant quality were rated as for Expt. 1, but on 25 Sept., 15 Oct., and 5 Nov. 2009. The number of flowers produced per plant was recorded weekly from 25 Sept. 2009 through 20 Nov. 2009. Plant quality was rated three times as described previously, but on 25 Sept., 15 Oct., and 5 Nov. 2009.

Two commercial cultivars, Bimini and Pensacola, were included in Expt. 1 and Expt. 2 as control (control) cultivars. They are cut flower-type cultivars and have been commonly used to produce gerbera in large (20cm-diameter) containers (Sunshine States Carnations, Inc., Hobe Sound, FL). The experiment design was a randomized complete block design with five (Expt. 1) or eight (Expt. 2) replications. The experimental unit was a single containerized plant. Data were analyzed using PROC GLM in the SAS software (SAS Inst., Cary, NC) and mean separation was done using the least significant difference at $P=0.05$.

UFGE 4141. UFGE 4141 came into flowering 26 to $31 \mathrm{~d}$ earlier than the controls in Expt. 1 and 5 to $10 \mathrm{~d}$ earlier in Expt. 2 (Table 1). Peduncles of UFGE 4141 ranged from 41.6 cm (Expt. 1) to $51.8 \mathrm{~cm}$ (Expt. 2), 9 to $15 \mathrm{~cm}$ shorter than that of the controls, but were 2 to $14 \mathrm{~cm}$ taller than that of the other five cultivars (Table 1). Flowers of UFGE 4141 averaged $11.6 \mathrm{~cm}$ in diameter in Expt. 1 and $12.9 \mathrm{~cm}$ in Expt. 2, the largest among all entries tested (Table 1). Flower quality ratings of UFGE 4141 were 3.8 to 4.2 , similar to that of 'Pensacola', but it was lower than that of 'Bimini' (Table 1). In both experiments, UFGE 4141 produced significantly more flowers ( $87 \%$ to $144 \%$ more than 'Bimini' and $300 \%$ more than 'Pensacola') (Table 1). The plant quality rating of UFGE 4141 was 3.7 and 4.4 in Expt. 1 and Expt. 2, respectively, significantly higher than that of the controls (Table 1).

$U F G E$ 7014. It came into flowering $49.6 \mathrm{~d}$ after transplanting in Expt. 1, 14 to 19 d earlier than the controls, and $42.3 \mathrm{~d}$ after transplanting in Expt. 2, 7 to $13 \mathrm{~d}$ earlier than the controls (Table 1). Peduncles of UFGE 7014 averaged 37.1 to $41.9 \mathrm{~cm}, \approx 60 \%$ to $70 \%$ shorter than the controls' peduncle lengths (Table 1). The flower size of UFGE 7014 was $11.1 \mathrm{~cm}$ in Expt. 1 and $10.7 \mathrm{~cm}$ in Expt. 2, similar to those of the controls (Table 1). Flower quality of UFGE 7014 was rated very high (5.0 in Expt. 1 and 4.7 in Expt. 2), similar to that of 'Bimini' (5.0 to 4.8) and higher than that of 'Pensacola' (4.1 to 4.3) (Table 1). UFGE 7014 produced an average of 7.6 and 9.0 flowers in Expt. 1 and Expt. 2, respectively, significantly more than the controls (3.0 and 5.5 flowers for 'Bimini' and 1.4 and 2.5 flowers for 'Pensacola') (Table 1). Plant quality ratings of UFGE 7014 were 4.7 in Expt. 1 and 4.9 in Expt. 2, consistently significantly higher than those of the controls (3.1 to 3.3) (Table 1).

Table 1. Horticultural characteristics and flower counts of six new gerbera cultivars, UFGE 4141, UFGE 7014, UFGE 7015, UFGE 7023, UFGE 7032, and UFGE 7034, and two commercial cultivars, Bimini and Pensacola, grown in Winter 2008 and Spring 2009 (Expt. 1) and Summer and Fall 2009 (Expt. 2) in Wimauma, FL. ${ }^{\mathrm{z}}$

\begin{tabular}{|c|c|c|c|c|c|c|}
\hline Cultivars & $\begin{array}{c}\text { Days to first } \\
\text { open flowers (no.) }\end{array}$ & $\begin{array}{l}\text { Peduncle } \\
\text { ht }(\mathrm{cm})\end{array}$ & $\begin{array}{c}\text { Flower } \\
\text { size }(\mathrm{cm})\end{array}$ & $\begin{array}{l}\text { Flower } \\
\text { quality }^{\mathrm{y}}\end{array}$ & $\begin{array}{c}\text { Plant } \\
\text { quality }^{\mathrm{x}}\end{array}$ & $\begin{array}{c}\text { Flower } \\
\text { counts }^{\mathrm{w}} \text { (no.) }\end{array}$ \\
\hline & \multicolumn{6}{|c|}{ Expt. 1 (9 Dec. 2008 to 17 Mar. 2009) } \\
\hline UFGE 4141 & $37.8 \mathrm{de}$ & $41.6 \mathrm{c}$ & $12.9 \mathrm{a}$ & $3.8 \mathrm{c}$ & $3.7 \mathrm{~b}$ & $5.6 \mathrm{bc}$ \\
\hline UFGE 7014 & $49.6 \mathrm{~cd}$ & $37.1 \mathrm{~d}$ & $11.1 \mathrm{c}$ & $5.0 \mathrm{a}$ & $4.7 \mathrm{a}$ & $7.6 \mathrm{ab}$ \\
\hline UFGE 7015 & $52.2 \mathrm{bc}$ & $39.0 \mathrm{~cd}$ & $10.2 \mathrm{~d}$ & $4.5 \mathrm{ab}$ & $4.8 \mathrm{a}$ & $9.6 \mathrm{a}$ \\
\hline UFGE 7023 & $36.2 \mathrm{e}$ & $29.4 \mathrm{e}$ & $12.9 \mathrm{a}$ & $3.7 \mathrm{c}$ & $4.5 \mathrm{a}$ & $7.8 \mathrm{ab}$ \\
\hline UFGE 7032 & 41.2 cde & $38.6 \mathrm{~d}$ & $11.0 \mathrm{c}$ & $4.8 \mathrm{a}$ & $3.9 \mathrm{~b}$ & $6.2 \mathrm{~b}$ \\
\hline UFGE 7034 & 39.8 cde & $37.9 \mathrm{~d}$ & $12.1 \mathrm{~b}$ & $4.9 \mathrm{a}$ & $4.5 \mathrm{a}$ & $10.2 \mathrm{a}$ \\
\hline Bimini & $64.0 \mathrm{ab}$ & $57.8 \mathrm{a}$ & $11.1 \mathrm{c}$ & $5.0 \mathrm{a}$ & $3.1 \mathrm{c}$ & $3.0 \mathrm{~cd}$ \\
\hline Pensacola & $68.8 \mathrm{a}$ & $51.6 \mathrm{~b}$ & $11.9 \mathrm{bc}$ & $4.1 \mathrm{bc}$ & $3.3 \mathrm{c}$ & $1.4 \mathrm{~d}$ \\
\hline $\operatorname{LSD}(P \leq 0.05)$ & 12.8 & 2.8 & 0.8 & 0.5 & 0.5 & 2.7 \\
\hline
\end{tabular}

\begin{tabular}{|c|c|c|c|c|c|c|}
\hline \multirow[b]{2}{*}{ UFGE 4141} & \multicolumn{6}{|c|}{ Expt. 2 (13 Aug. to 20 Nov. 2009) } \\
\hline & $44.6 \mathrm{~d}$ & $51.8 \mathrm{~b}$ & $11.6 \mathrm{a}$ & $4.2 \mathrm{~cd}$ & $4.4 \mathrm{a}$ & $11.9 \mathrm{a}$ \\
\hline UFGE 7014 & $42.3 \mathrm{~d}$ & $41.9 \mathrm{c}$ & $10.7 \mathrm{~b}$ & $4.7 \mathrm{abc}$ & $4.7 \mathrm{a}$ & $9.0 \mathrm{~b}$ \\
\hline UFGE 7023 & $49.8 \mathrm{bc}$ & $40.5 \mathrm{~cd}$ & $11.3 \mathrm{a}$ & $3.9 \mathrm{~d}$ & $5.0 \mathrm{a}$ & $4.9 \mathrm{c}$ \\
\hline UFGE 7032 & $45.3 \mathrm{~cd}$ & $37.9 \mathrm{~d}$ & $10.0 \mathrm{c}$ & $4.8 \mathrm{ab}$ & $4.8 \mathrm{a}$ & $9.0 \mathrm{~b}$ \\
\hline UFGE 7034 & $41.3 \mathrm{~d}$ & $38.9 \mathrm{~cd}$ & $10.6 \mathrm{~b}$ & $4.9 \mathrm{a}$ & $4.6 \mathrm{a}$ & $12.1 \mathrm{a}$ \\
\hline Bimini & $50.1 \mathrm{~b}$ & $61.5 \mathrm{a}$ & $10.6 \mathrm{~b}$ & $4.8 \mathrm{ab}$ & $3.3 \mathrm{~b}$ & $5.5 \mathrm{c}$ \\
\hline Pensacola & $55.8 \mathrm{a}$ & $62.5 \mathrm{a}$ & $11.2 \mathrm{ab}$ & $4.3 \mathrm{bcd}$ & $3.2 \mathrm{~b}$ & $2.5 \mathrm{~d}$ \\
\hline $\operatorname{LSD}(P \leq 0.05)$ & 4.5 & 3.9 & 0.6 & 0.5 & 0.6 & 1.7 \\
\hline
\end{tabular}

zPlants were grown from tissue culture liners (Agri-Starts Inc., Apopka, FL) in trade gallon plastic containers filled with Fafard 3B potting mix amended with $15 \mathrm{~N}-3.9 \mathrm{P}-10 \mathrm{~K}$ Osmocote controlled-release fertilizer $\left(5.28 \mathrm{~kg} \cdot \mathrm{cm}^{-3}\right)$ and MicroMax trace element fertilizer $\left(1.05 \mathrm{~kg} \cdot \mathrm{cm}^{-3}\right)$

${ }^{y}$ Flower quality was rated on a 1 to 5 scale: 1 = very poor; 3 = fair, some blemishes, but acceptable; and $5=$ excellent, bright, uniform, and no blemishes. The flower quality rating of each cultivar was the mean of five (Expt. 1) or eight (Expt. 2) replicates and each replicate had at least three subsamples.

xPlant quality was rated using a 1 to 5 scale: 1 = few leaves or long petioles, container surface visible, very poor and unacceptable as flowering pot plants; $3=$ fair and meeting the minimum standard for marketability; and 5 = excellent, full, attractive, symmetrical plants. The plant quality rating value in Expt. 1 was the mean of five replicates averaged over three evaluation times (20 Jan., 3 Feb., and 17 Feb. 2009), and the plant quality rating value in Expt. 2 was the mean of eight replicates averaged over three evaluation times (25 Sept., 15 Oct., and 5 Nov. 2009).

wFlower count data were collected over 9 weeks from 20 Jan. to 17 Mar. 2009 in Expt. 1 and 9 weeks from 25 Sept. to 20 Nov. 2009 in Expt. 2. Each value represents the mean of five (Expt. 1) or eight (Expt. 2) replicates. All data within columns for both experiments with the same letter are not statistically different at $P \leq 0.05$. LSD $=$ least significant difference.

$U F G E$ 7015. It behaved much like its sibling UFGE 7014 with average flowering $52.2 \mathrm{~d}$ after transplanting (Table 1). Flowers of UFGE 7015 were averaged $10.2 \mathrm{~cm}$, smaller than those of the controls and other entries in the experiment, but the flowers were attractive and received a score of 4.5 (Table 1). UFGE 7015 was among the most floriferous, producing an average of 9.6 flowers within 9 weeks in Expt. 1, only second to UFGE 7034 (Table 1). It became the most productive cultivar among the entries when grown under natural powdery mildew disease pressures (refer to subsequently). Plants of UFGE 7015 developed numerous leaves that formed full, symmetrical plants and received a quality rating of 4.8 , significantly higher than that of the controls (Table 1).

$U F G E$ 7023. It was the earliest cultivars to open flowers in Expt. 1, 36.2 d after transplanting, which was 27.8 to $32.6 \mathrm{~d}$ earlier than the controls (Table 1). In Expt. 2, UFGE 7032 came into flowering $49.8 \mathrm{~d}$ after transplanting, $\approx 8.5 \mathrm{~d}$ later than the earliest one (Table 1). The delay in flowering might be caused by the tissue culture liners of UFGE 7023 used in Expt. 2 being $\approx 10$ d younger than the liners of the rest of the entries. Peduncles of UFGE 7023 were $29.4 \mathrm{~cm}$ in Expt. 1 and $40.5 \mathrm{~cm}$ in Expt. 2, 57\% to $65 \%$ of that of the controls and the shortest among all the entries (Table 1). Flowers of UFGE
7023 were $12.9 \mathrm{~cm}$ (Expt. 1) and $11.3 \mathrm{~cm}$ (Expt. 2), thus being among the largest. Flower quality ratings of UFGE 7023 were 3.7 (Expt. 1) and 3.9 (Expt. 2), acceptable but lower than that of the controls and the other entries (Table 1). Plant quality ratings of UFGE 7023 were 4.5 (Expt. 1) and 5.0 (Expt. 2 ), both significantly higher than those of the controls (Table 1).

$U F G E$ 7032. It opened flowers 41.2 (Expt. 1) and 45.3 (Expt. 2) days after transplanting (Table 1). Peduncles of UFGE 7032 were 38.6 cm (Expt. 1) and $37.9 \mathrm{~cm}$ (Expt. 2), 60\% to $75 \%$ of that of the controls (Table 1). Flowers of UFGE 7032 were 11.0 (Expt. 1) and $10.0 \mathrm{~cm}$ (Expt. 2), similar to (Expt. 1) or smaller than (Expt. 2) those of the controls (Table 1). Flower quality of UFGE 7032 was rated high, 4.8 in both experiments, which was similar to that of 'Bimini' (5.0 to 4.8) and higher than that of 'Pensacola' (4.1 to 4.3) (Table 1). UFGE 7032 produced 6.2 and 9.0 flowers in Expt. 1 and Expt. 2, respectively, significantly more than the controls (3.0 and 5.5 flowers for 'Bimini' and 1.4 and 2.5 flowers for 'Pensacola') (Table 1). Plant quality of UFGE 7032 was rated 3.9 in Expt. 1 and 4.8 in Expt. 2, significantly higher than that of the controls (3.1 to 3.3) (Table 1).

UFGE 7034. It produced 10.2 and 12.1 flowers in Expt. 1 and Expt. 2, one- to fourfold more than the controls and also more than other new cultivars in the experiments (Table 
1). Thus, it was the most floriferous cultivar among all the entries. UFGE 7034 was among the earliest, opening flowers within 39.8 to $41.3 \mathrm{~d}$ after transplanting, 24 to $29 \mathrm{~d}$ earlier than the controls in Expt. 1 and 9 to 15 d earlier in Expt. 2 (Table 1). Flowers of UFGE 7034 were $12.1 \mathrm{~cm}$ in Expt. 1 and $10.6 \mathrm{~cm}$ in Expt. 2 and received a very high quality rating, 4.9 in both experiments, similar to that of 'Bimini' but 0.6 to 0.8 higher than that of 'Pensacola' (Table 1). Peduncles of UFGE 7034 were 37.8 to $38.9 \mathrm{~cm}, 60 \%$ to $75 \%$ of that of the controls, and falling within the range of desirable heights for use in large containers (Table 1). Plant quality ratings of UFGE 7034 were 4.5 in Expt. 1 and 4.6 in Expt. 2, among the highest in both experiments (Table 1).

\section{Powdery Mildew Susceptibility}

Two experiments (Expt. 3 and Expt. 4) were conducted in parallel with Expt. 1 and Expt. 2 to evaluate gerberas' resistance (or susceptibility) to powdery mildew. Previously, the causal pathogen of powdery mildew on gerbera at this experiment site was identified as Podosphaera (syn. Sphaerotheca) fusca (Fr.) S. Blumer (Moyer et al., 2008). Tissue culture liners and potting mix were the same as Expts. 1 and 2, but the potted plants were grown under a plastic tunnel within a screen house with $\approx 45 \%$ light exclusion. Fungicides were not applied throughout the experiments to subject the plants to natural powdery mildew disease pressures. In Expt. 3, severity of powdery mildew on gerbera leaves was assessed at Weeks 8 (4 Feb. 2009), 10 (18 Feb. 2009), 12 (4 Mar. 2009), and 14 (18 Mar. 2009) after transplanting, and in Expt. 4, powdery mildew severity was assessed at Weeks 8 (15 Oct. 2009), 10 (29 Oct. 2009), and 12 (12 Nov. 2009) after transplanting using a scale of 1 to 10 as described by Hausbeck et al. (2002). 'Bimini' and 'Pensacola' were included in both experiments as controls. A randomized complete block design was used with five (Expt. 3) or eight (Expt. 4) replications. The experimental unit was a single containerized plant. Data were analyzed using PROC GLM in the SAS software (SAS Inst.) and mean separation was done using the least significant difference at $P=0.05$.

In Expt. 3, powdery mildew symptoms began to appear at Week 8 after transplanting, and the average severity rating of all entries increased rapidly in the next 6 weeks: from 2.2 on $18 \mathrm{Feb}$. to 4.8 on 4 Mar. and then to 6.9 on 18 Mar. (data not shown). Similarly, in Expt. 4 , the average severity rating of all entries in the experiment increased from 1.5 on 15 Oct. to 5.3 on 29 Oct. and then 7.0 on 12 Nov. (data not shown). This is in agreement with other reports (Moyer and Peres, 2008) that have indicated that powdery mildew develops rapidly when favorable environmental conditions become available. In both experiments, the controls had the highest severity ratings at the end of the evaluation periods, 8.0 to 8.6 in Expt. 3 and 9.6 to 9.8 in Expt. 4 (Table 2).

UFGE 4141 and UFGE 7034 were significantly less susceptible to powdery mildew than the controls in Expt. 4 throughout the evaluation (Table 2). They also had lower severity ratings than the controls in Expt. 3, but the differences were not statistically significant. UFGE 4141 and UFGE 7034 were the most floriferous in Expt. 4 and moderately floriferous in Expt. 3 when natural powdery mildew disease pressure existed (Table 2). Similarly, UFGE 7014 was significantly less susceptible to powdery mildew than the controls in Expt. 4 throughout the evaluation. It had lower severity ratings than the controls in Expt. 3, but the differences were not statistically significant. UFGE 7014 remained to be more floriferous than the controls in Expt. 3 and Exp. 4.

UFGE 7015's powdery mildew severity ratings averaged 3.6 at Week 14 (Table 2), significantly lower than the ratings of the controls (8.0 to 8.6), indicating a considerable level of powdery mildew resistance in this cultivar. Its rating was also significantly lower than other UFGE gerberas. This high level of powdery mildew resistance might be the reason that UFGE 7015 produced the highest number of flowers in Expt. 3 (Table 2).

Table 2. Powdery mildew severity ratings and flower counts of six new gerbera cultivars, UFGE 4141, UFGE 7014, UFGE 7015, UFGE 7023, UFGE 7032, and UFGE 7034, and two commercial cultivars, Bimini and Pensacola, grown under natural powdery mildew pressure in Winter 2008 and Spring 2009 (Expt. 3) and Summer and Fall 2009 (Expt. 4) in Wimauma, FL.

\begin{tabular}{|c|c|c|c|c|}
\hline \multirow[b]{2}{*}{ Cultivars } & \multicolumn{2}{|c|}{ Expt. 3} & \multicolumn{2}{|c|}{ Expt. 4} \\
\hline & $\overline{\mathrm{PM}_{\text {ratings }} \mathrm{z}}$ & Flower counts $^{y}$ & $\overline{\text { PM ratings }}{ }^{x}$ & Flower counts ${ }^{\mathrm{w}}$ \\
\hline$\overline{\text { UFGE } 4141}$ & $6.8 \mathrm{ab}$ & $4.4 \mathrm{~cd}$ & $5.3 \mathrm{c}$ & $5.6 \mathrm{a}$ \\
\hline UFGE 7014 & $6.6 \mathrm{ab}$ & $5.6 \mathrm{bc}$ & $7.0 \mathrm{~b}$ & $4.3 \mathrm{~b}$ \\
\hline UFGE 7015 & $3.6 \mathrm{c}$ & $7.6 \mathrm{a}$ & & \\
\hline UFGE 7023 & $7.8 \mathrm{ab}$ & $6.0 \mathrm{abc}$ & $6.0 \mathrm{c}$ & $3.5 \mathrm{c}$ \\
\hline UFGE 7032 & $7.4 \mathrm{ab}$ & $6.2 \mathrm{ab}$ & $6.1 \mathrm{bc}$ & $4.6 \mathrm{ab}$ \\
\hline UFGE 7034 & $6.2 \mathrm{~b}$ & $5.0 \mathrm{bc}$ & $5.5 \mathrm{c}$ & $5.1 \mathrm{ab}$ \\
\hline Bimini & $8.0 \mathrm{ab}$ & $3.2 \mathrm{~d}$ & $9.4 \mathrm{a}$ & $2.6 \mathrm{~d}$ \\
\hline Pensacola & $8.6 \mathrm{a}$ & $3.0 \mathrm{~d}$ & $9.8 \mathrm{a}$ & $1.1 \mathrm{e}$ \\
\hline $\operatorname{LSD}(P \leq 0.05)$ & 2.1 & 1.8 & 0.9 & 1.1 \\
\hline
\end{tabular}

z, xPowdery mildew severity was rated on 18 Mar. 2009, 14 weeks after transplanting in Expt. 3, and 12 Nov. 2009, 12 weeks after transplanting in Expt. 4, on a scale of 1 to 10 as described by Hausbeck et al. (2002): $1=$ no disease; $2=$ trace to $10 \% ; 3=10 \%$ to $20 \% ; 4=20 \%$ to $30 \% ; 5=30 \%$ to $40 \% ; 6=40 \%$ to $50 \% ; 7=50 \%$ to $60 \% ; 8=60 \%$ to $70 \% ; 9=70 \%$ to $80 \%$; and $10=80 \%$ to $100 \%$ of leaf surface covered with powdery mildew. y, wotal number of flowers produced per plant over nine weeks from 20 Jan. to 17 Mar. 2009 (Expt. 3) or from 25 Sept. to 20 Nov. 2009 (Expt. 4).

All data within columns for both experiments with the same letter are not statistically different at $P \leq 0.05$. LSD $=$ least significant difference.

UFGE 7023 and UFGE 7032 had significantly lower powdery mildew severity ratings than the controls in Expt. 4 (6.0 to 6.1 versus 9.4 to 9.8 ) (Table 2). However, their ratings in Expt. 3 were very close to those of the controls. In both experiments, UFGE 7023 and UFGE 7032 produced significantly more flowers than the controls.

In summary, UFGE 4141, UGGE 7014, UFGE 7015, UFGE 7023, UFGE 7032, and UFGE 7034 produced high-quality plants and bright-colored flowers in the experiments. They came into flowering earlier and produced more flowers than the controls. UFGE 7015 showed a high level of resistance to powdery mildew, and the rest of the UFGE gerberas also showed improved resistance to powdery mildew compared with control cultivars. Additionally, these new gerberas performed superbly in growers' trials (Ball Horticultural Company, West Chicago, IL; Costa Farms, Miami, FL; Pure Beauty Farms, Miami, FL; personal communication) and growers have shown strong interest in producing these gerberas commercially.

\section{Availability}

Plant patents will be sought from the U.S. Patent and Trademark Office and plant patent rights will be assigned to the University of Florida, Board of Trustees. Propagation and production will be licensed by the Florida Foundation Seed Producers, Inc., P.O. Box 110200, Gainesville, FL 32611. Information on propagation agreements can be obtained from the Florida Foundation Seed Producers, Inc.

\section{Literature Cited}

Behnke, M. 1984. Gerbera production. Grower Talks 47:94-97.

Channel, C. 2005. Gerbera trials rate plants. GM Pro 25:30-31.

Chase, A.R. 2001. 2001 Update on powdery mildew control. GPN-Greenhouse Product News 11:44-46.

Dole, J.M. and H.F. Wilkins. 1999. Gerbera, p. 356-361. In: Dole, J.M. and H.F. Wilkins (eds.). Floriculture, principles and species. Prentice Hall, Upper Saddle River, NJ.

Hansen, H.V. 1999. A story of the cultivated gerbera. The New Plantsman (Royal Hort. Soc.) 6:85-95.

Hausbeck, M.K., W.R. Quackenbush, and S.D. Linderman. 2002. Evaluation of cultivars of African daisy for resistance to powdery mildew, 2002. B\&C Tests 18:O0004.

Moyer, C. and N.A. Peres. 2008. Powdery mildew of gerbera daisy. 12 Nov. 2009. <http://edis. ifas.ufl.edu/pdffiles/PP/PP25700.pdf>.

Moyer, C., N.A. Peres, L.E. Datnoff, E.H. Simmone, and Z. Deng. 2008. Evaluation of silicon for managing powdery mildew on gerbera daisy. J. Plant Nutr. 31:2131-2144.

Price, J.F., C. Nagle, and E. McCord, Jr. 2003. Insect and mite management suggestions for commercial gerbera production. 12 Nov. 2009. <http:// edis.ifas.ufl.edu/pdffiles/IG/IG00400.pdf>.

Rogers, M.N. and B.O. Tjia. 1990. Gerbera production for cut flowers and pot plants. Timber Press, Portland, OR.

Royal Horticultural Society. 1986. Royal Horticultural Society colour chart. Royal Hort. Soc., London, UK. 